\title{
Pleural Effusions
}

\section{Introduction}

Pleural effusion is defined as a fluid collection between the pleural leaves due to local/systemic disease of the pleura, lung or extrapulmonary organs. Normally, 0.1 to $0.2 \mathrm{ml} / \mathrm{kg}$ of fluid is present in the pleural leaves to facilitate pleural movement. When the balance between the production and reabsorption of this fluid deteriorates, it becomes pleural effusion [1].

Mechanisms of pleural effusion can be summarized as $[1,2]$.

- Increased hydrostatic pressure in the microvascular circulation

- Decreased oncotic pressure in the microvascular circulation

- Increased negative pressure in the pleural space

- Separation of pleural leaves

- Increased permeability in the microvascular circulation

- Decrease in lymphatic drainage capacity

- Transition from the abdomen to the thorax

The prevalence of pleural effusion is estimated at 320/100000 and is seen as equal in both genders. However, malignant effusions are more common in women due to breast and gynecological cancers, while malignant mesothelioma and pancreatitisassociated effusions are more frequent in males [3].

\section{Causes of Pleural Effusion}

\section{Transudative pleural effusions}

- Congestive heart failure

- Cirrhosis

-Nephrotic syndrome

-Kidney failure

-Peritoneal dialysis

-Urinothorax

-Myxoedema

-Hypoalbuminemia

-Atelectasis

- Sarcoidosis

-Pulmonary embolism

\section{Fundla Ozturk Incekara*, Deniz Kaygusuz Tikici and Hakan Nomenoglu}

\author{
Department of Thoracic Surgery, Ataturk \\ Chest Diseases and Thoracic Surgery \\ Trained and Research Hospital, Ankara, \\ Turkey

\section{* Corresponding author: Funda Ozturk Incekara} \\ ほ drfundaincekara@gmail.com \\ Department of Thoracic Surgery, Ataturk \\ Chest Diseases and Thoracic Surgery \\ Trained and Research Hospital, Ankara, \\ Turkey.
}

Tel: 00905057682387

Citation: Incekara FO, Tikici DK, Nomenoglu H (2018) Pleural Effusions. Insights Chest Dis Vol.3 No.1:1

-Vena cava superior syndrome

-Meigs syndrome

-Constrictive pericarditis

-Cerebrospinal fluid leakage to pleural space

Exudative pleural effusion

-Neoplastic diseases

-Metastatic diseases

-Mesothelioma

- Lymphoma

-Infectious diseases

-Bacterial infections

-Tuberculosis

-Fungal infections

-Parasitic infections

-Viral infections 
-Pulmonary embolism

- Cardiovascular diseases

- Coronary artery bypass surgery

-Postcardiac injury syndrome

-Pericardial diseases

- Gastrointestinal diseases

- Pancreatic diseases

-Subphrenic, intrahepatic, intrasplenic abscess

-Esophageal perforation

-Abdominal surgery

-Diaphragm hernia

- Liver transplantation

- Collagen vascular diseases

-Rheumatoid pleurisy

-Systemic lupus erythematosus

-Drug induced lupus

-Immunoblastic lymphadenopathy

-Sjögren's syndrome

- Familial Mediterranean fever

-Churg-Strauss syndrome

-Wegener granulomatosis

- Gynecology and Obstetrics

- Ovarian hyperstimulation syndrome

-Fetal pleural effusion

-Postpartum pleural effusion

-Meigs syndrome

-Endometriosis

-Diseases of lymphatic system

-Chylothorax

-Yellow nail syndrome

- Lymphangioleiomyomatosis

-Drug induced

-Nitrofurantoin

-Dantrolene

-Methylsergide

- Ergot alkaloids

-Amiodarone

-Interleukin-2

-Procarbazine
-Methotrexate

-Clozapine

-Mitomycin

-Bleomycin

-Bromocriptine

Other

-Asbestos exposure

- Lung transplantation

-Bone marrow transplantation

-Trapped lung

- Radiation exposure

-Drowning

-Amyloidosis

-Thoracotomy

-Electrical burns

-Extramedullary hematopoiesis

-ARDS

- Syphilis

- latrogenic pleural effusions

- Haemothorax

-Idiopathic pleural effusions

\section{Diagnostic Approach in Pleural Effusion}

1. Clinic presentation: Patient's history and physical examination

2. Radiology: Conventional radiography, ultrasonography, computerized tomography

3. Thoracentesis: pleural fluid analysis

4. Bronchoscopy

5. Pleural fine needle biopsy

6. Video assisted thoracoscopic surgery (VATS) - Tauroctony (open pleural biopsy)

\section{Clinical approach}

Pleural effusion disturbs the patient's respiratory mechanics and leads to restrictive type of respiratory failure. Total lung capacity, functional capacity and forced vital capacity decrease. Ventilation/perfusion imbalance and/or ventricular diastolic collapse may occur depending on the amount of atelectasis caused by effusion. Therefore, the most common symptom is dyspnea and mild, nonproductive cough. Depending on the underlying disease, night sweats, weight loss, hemoptysis and high fever can also be seen.

Physical examination findings may vary depending on the amount of effusion. It is clinically nonexistent until reaching a volume of $300 \mathrm{ml}$. However, when this amount is exceeded; less participation 
to the respiration of the hemithorax, matty in the percussion examination, decreased vocal fremitus, decrease or absence of breath sounds, pleural rub may occur. Mediastinal shift may occur when the pleural effusion reaches $1000 \mathrm{ml}$. This results in a physical examination of the trachea as a counter-deviation to the opposite side. Depending on the underlying disease, peripheral edema, swelled neck veins, S3 rhythm, cutaneous findings or lymphadenopathies may be detected [4-7].

\section{Radiological approach}

The first procedure to be performed in a patient with suspicion of pleural effusion on physical examination is to evaluate the patient with radiological examinations. Approximately $50 \mathrm{ml}$ of fluid can be seen on the lateral chest radiograph and $200 \mathrm{ml}$ of fluid can be seen on posterior-anterior chest radiograph. However, in radiographs taken in a supine position, the fluid does not cause significant blunting of the sinuses while it spreads to the entire thorax (Figure 1).

Ultrasound can reveal important findings in cases where effusion is suspected. It helps to distinguish solid structures, to locate locular or small amount of pleural effusion or to perform thoracentesis safely.

Computed thorax tomography is useful in the complicated cases or situations where anatomy cannot be clearly demonstrated. However, it is more appropriate to see the pathology after the fluid has been emptied in order to reveal pathologies that may be in the atelectatic region where caused by the effusion (Figure 2) $[6,7]$.

\section{Thoracentesis}

The easiest way to sample the pleural effusion is thoracentesis. Thoracentesis allows us to know if the fluid is transudate or exudate. This discrimination is made with the Light criteria. Transudative fluids are low in protein content and develop as a result of imbalance between hydrostatic and oncotic forces that

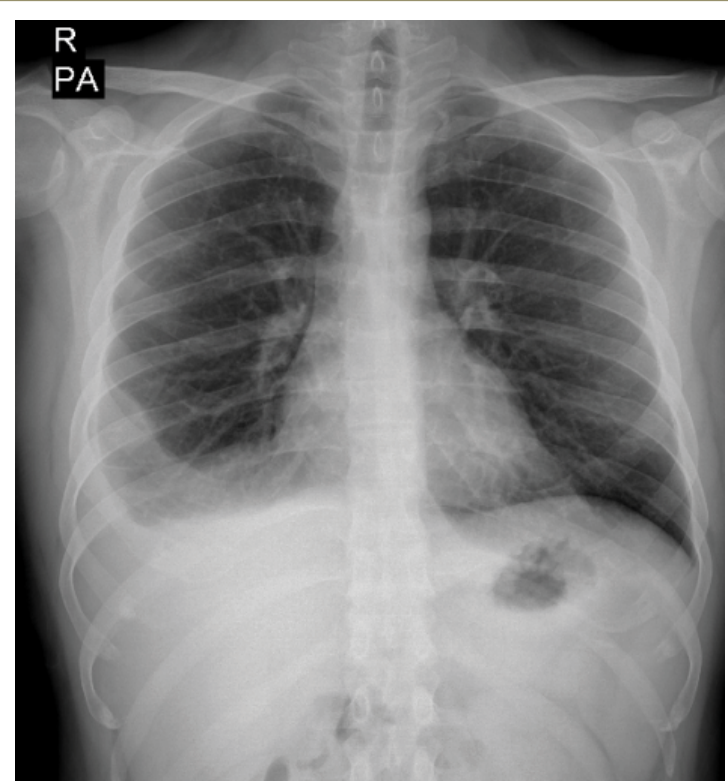

Figure 1 Radiological approach of pleural effusion.

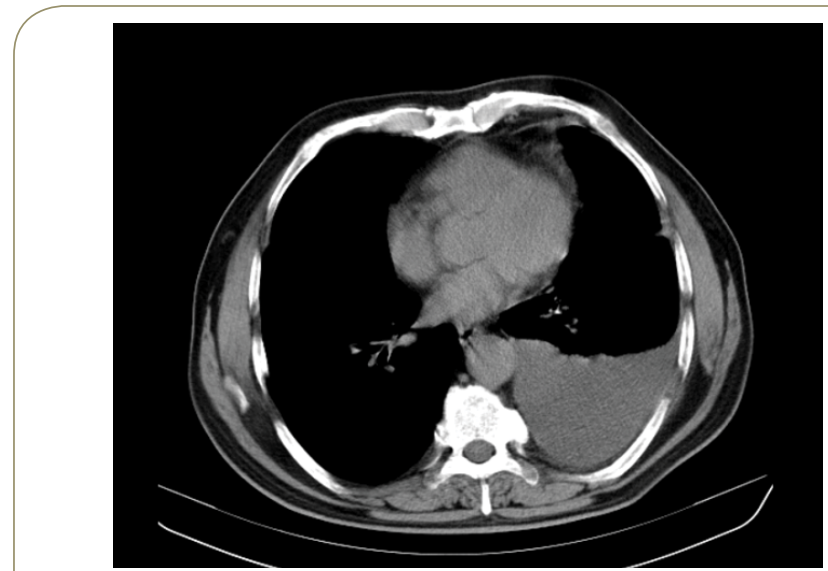

Figure 2 Atelectatic region caused by the effusion.

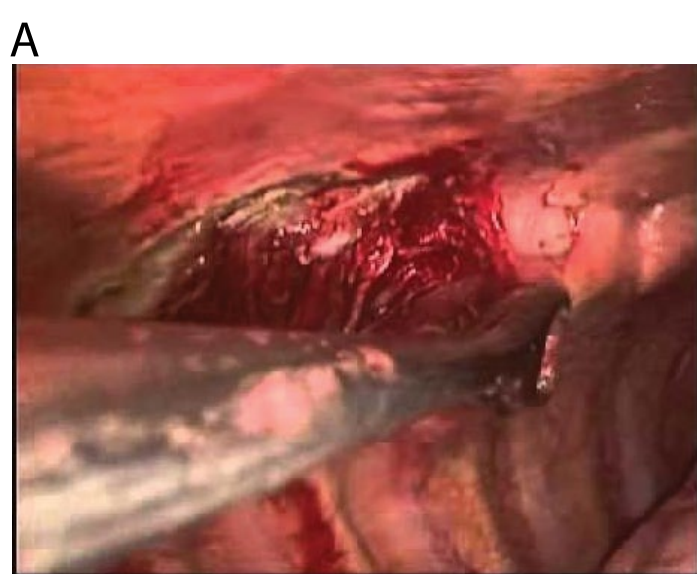

B

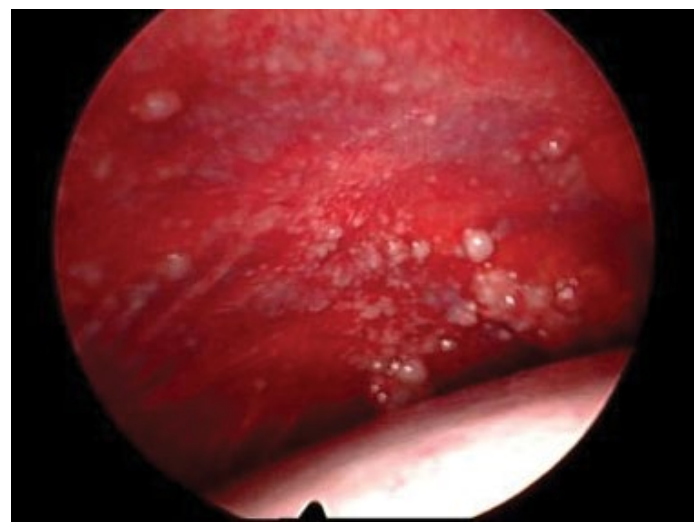

Figure 3 Open pleural biopsy with thoracotomy.

affect the pleural fluid cycle or as a result of lymphatic obstruction. Exudative fluids may occur due to increased permeability on the pleural surface and microvascular structures, and protein content is high. Discrimination of transudate/exudate is important for differential diagnosis and for the determination of treatment afterwards (Table 1) [1,2].

Pleural fluid biochemistry and blood biochemistry have to be studied together and simultaneously for the evaluation of the Light criteria. However, differentiation can be made by evaluating 
Table 1 Light criteria.

$\begin{array}{ccc}\text { Pleural fluid protein/serum protein } & >0.5 \\ \text { Pleural fluid LDH/serum LDH } & >0.6 & \text { Exudate } \\ \text { Pleural fluid LDH } & >2 / 3 \text { of normal serum LDH }\end{array}$

Table 2 Diagnostic approach according to appearance of pleural fluid.

\begin{tabular}{|c|c|}
\hline Color, turbidity, viscosity, odor & Diagnosis \\
\hline Light yellow color, clear & Transudatice effusion \\
\hline Straw yellow, fibrin nets & Tuberculosis \\
\hline Viscous, burgundy red & Malignant Pleural Mesothelioma \\
\hline In the appearance of chocolate sauce & Amoeba abscess \\
\hline Black & Aspergillosis \\
\hline Yellowish-green & Rheumatoid pleurisy \\
\hline Hemorrhagic & Trauma, malignancy \\
\hline White & Chylothorax, pseudochylothorax, empyema \\
\hline Pus & Empyema \\
\hline Food particles & Esophageal rupture \\
\hline Turbid appearence & Increased cellular ingredients, lipids \\
\hline Putrid smell & Anaerobic infections \\
\hline Urine smell & Urinothorax \\
\hline
\end{tabular}

Table 3 Diagnostic approach to pleural fluid according to cell dominance.

Hemorrhagic pleural effusion:
$>5.000 / \mathrm{mm}^{3}$ erythrocytes, pleural fluid Hct $>1 \%$
Hemothorax:
$>100,000 / \mathrm{mm}^{3}$ erythrocytes, pleural fluid/blood Hct $>0.5$
- Trauma
- Lung cancer
- Mesothelioma
- Pulmonary embolism
- Tuberculosis
- Coxsackie virus infection
- Postcardiac injury syndrome (PCIS)
- Asbestosis
- Hemorrhagic pancreatitis

Acute inflammation indicator

- Pneumonia

- Empyema

- Pulmonary embolism

Neutrophils

- Lung abscess

- Subphrenic abscess

- Tuberculosis (Early period)

- Pancreatitis

- $10 \%$ of transudative fluids 


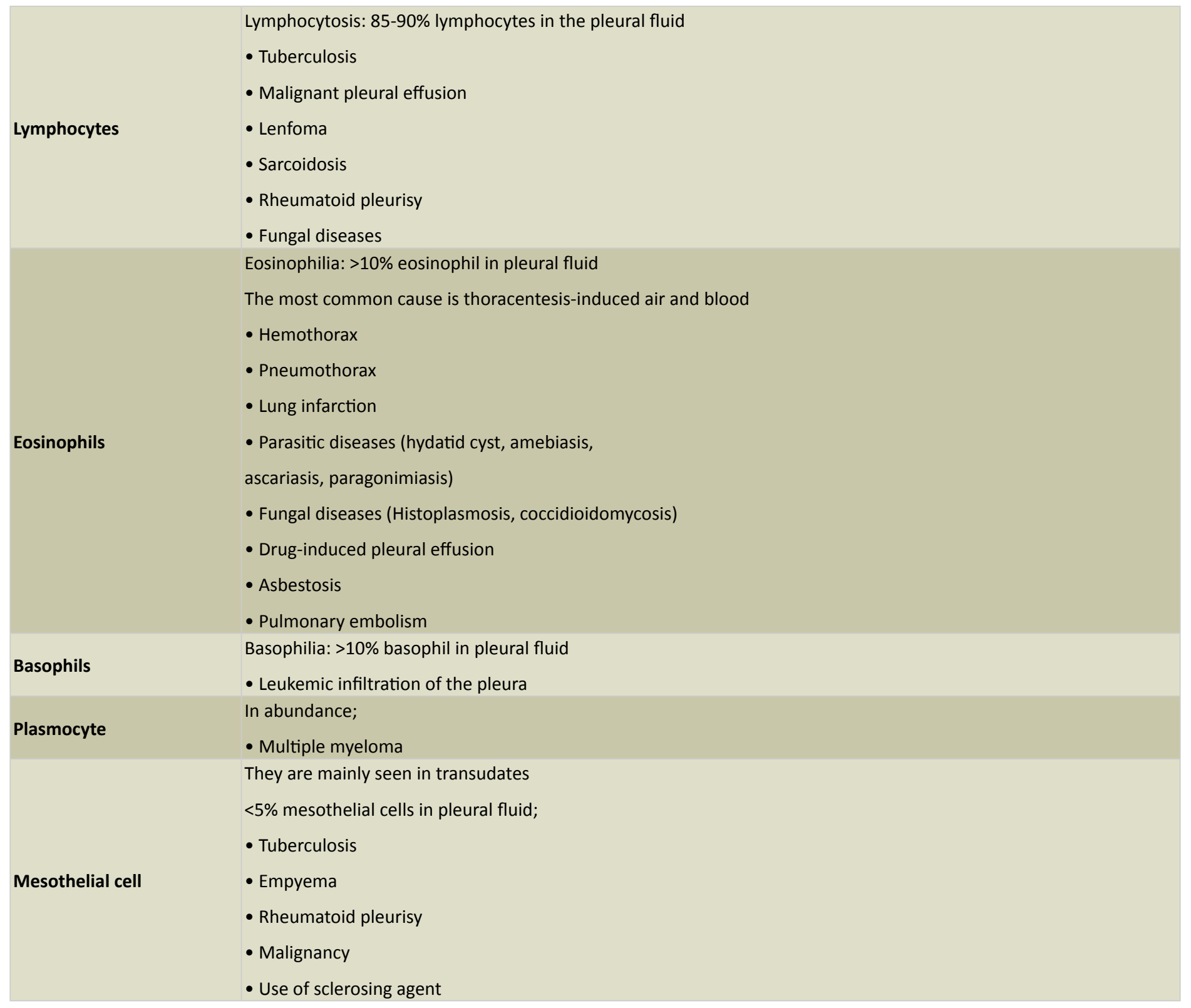

only pleural fluid biochemistry. The cholesterol level of the pleural fluid is $45 \mathrm{mg} / \mathrm{dl}$ and the pleural fluid protein value is over $2.9 \mathrm{~g} /$ $\mathrm{dl}$, which alone is sufficient for exudate diagnosis [4].

\section{The studies suggested to determine the etiology of pleural fluid are as follows:}

\section{Macroscopic appearance of the fluid}

2. Cell counting and differentiation in the pleural fluid

3. Pleural fluid smear and cultures

4. Pleural fluid glucose and LDH measurement

5. Cytologic evaluation of the pleural fluid

\section{Examination for tuberculosis}

Pleural fluid smear and cultures: Gram staining, bacteria, mycobacteria and fungus cultures should be performed routinely. Positivity may increase if planting directly to the medium just beside the patient $[3,4]$ (Table 2 ).
Cytologic examination of pleural fluid: If malignancy is suspected, pleural fluid cytology is a rapid, effective and noninvasive diagnostic method. Diagnosis positivity varies between $40-87 \%$. Experience of the pathologist, increased tumor burden, tumor growth in the pleural space, and 3 times repetition of cytology may increase the positivity $[3,4]$.

Examination in terms of tuberculosis: It is possible to diagnose tuberculosis by polymerase chain reaction (PCR) for adenosine deaminase (ADA), gamma interferon and mycobacterial DNA in the pleural fluid. When the gamma interferon level is above $5 \mathrm{U} /$ $\mathrm{ml}$, diagnose can be differentiated by nearly $100 \%$ of sensitivity and specificity. In addition, pleural fluid/serum gamma interferon ratio> 20 leads to differential diagnosis (Tables 3 and 4) [3,4].

\section{Bronchoscopy}

Diagnostic application, recommended in case of hemoptysis, atelectasis, parenchymal lesion, central lung lesion or massive pleural effusion $[4,5]$. 
Table 4 Biochemical examinations in pleural fluid diagnostic approach.

\begin{tabular}{|c|c|}
\hline Examination & Diagnosis \\
\hline $\begin{array}{l}\text { Pleural fluid glucose }<60 \mathrm{mg} / \mathrm{dL} \text { or } \\
\text { Pleural fluid/serum glucose }<0.5\end{array}$ & $\begin{array}{c}\text { Empyema } \\
\text { Rheumatoid pleurisy } \\
\text { Tuberculosis } \\
\text { Malignancy } \\
\text { Paragonimiasis } \\
\text { Haemothorax } \\
\text { Esophageal rupture } \\
\text { Churg-Strauss' syndrome } \\
\text { Urinothorax }\end{array}$ \\
\hline Conditions detected in pleural fluid $\mathrm{pH}<7.20$ & $\begin{array}{c}\text { Complicated parapneumonic effusion } \\
\text { Esophageal rupture } \\
\text { Rheumatoid pleurisy } \\
\text { Tuberculosis } \\
\text { Malignancy } \\
\text { Systemic acidosis } \\
\text { Haemothorax } \\
\text { Paragonimiasis } \\
\text { Urinothorax }\end{array}$ \\
\hline The lowest $\mathrm{pH}$ level in the pleural fluid & Esophageal rupture \\
\hline Low $\mathrm{pH}$ value in transudates & Urinothorax \\
\hline Conditions with pleural fluid LDH >1000 IU/L & $\begin{array}{c}\text { Empyema } \\
\text { Complicated parapneumonic effusion } \\
\text { Rheumatoid pleurisy } \\
\text { Paragonimiyazis } \\
\text { Collagen tissue diseases }\end{array}$ \\
\hline ADA (Adenosine deaminase) & $\begin{array}{l}>40 \mathrm{IU} / \mathrm{L} \text { differentiation of tuberculosis and malignancy } \\
\qquad>70 \mathrm{IU} / \mathrm{L} \text { Tuberculosis }\end{array}$ \\
\hline ADA elevation situations & $\begin{array}{l}\text { Tuberculosis } \\
\text { Rheumatoid pleurisy } \\
\text { Empyema } \\
\text { Lymphoma } \\
\text { Leukemia }\end{array}$ \\
\hline Pleural fluid / serum amylase $>1$ & $\begin{array}{c}\text { Acute pancreatitis } \\
\text { Pancreatic pseudocyst } \\
\text { Esophageal rupture } \\
\text { Malignancy } \\
\text { Ruptured ectopic pregnancy }\end{array}$ \\
\hline $\begin{array}{l}\text { Pleural fluid lysozyme }>20 \mu \mathrm{g} / \mathrm{mL} \text { or } \\
\text { Pleural fluid / Serum lysozyme }>1.2 \\
\text { Pleural fluid cholesterol }>90 \mathrm{mg} / \mathrm{dL}\end{array}$ & $\begin{array}{l}\text { Distinguishes tuberculous pleurisy from malignancy. Tuberculosis } \\
\text { possibility increases. }\end{array}$ \\
\hline Pleural fluid triglyceride $>110 \mathrm{mg} / \mathrm{dL}$ & Chylothorax \\
\hline $\begin{array}{l}\text { Pleural fluid triglyceride is between } 50-110 \mathrm{mg} / \mathrm{dL} \text { and } \\
\text { chylomicrons in lipoprotein analysis }\end{array}$ & Chylothorax \\
\hline $\begin{array}{l}\text { Pleural fluid triglyceride }<50 \mathrm{mg} / \mathrm{dL} \text { and } \\
\text { Pleural fluid cholesterol }>250 \mathrm{mg} / \mathrm{dL}\end{array}$ & Pseudochylothorax \\
\hline Pleural fluid hyaluronic acid $>1 \mathrm{mg} / \mathrm{mL}$ M. & Mesothelioma \\
\hline Pleural fluid / serum creatinine $>1$ & Urinothorax \\
\hline
\end{tabular}

\section{Pleural needle biopsy}

It is indicated in patients who cannot be diagnosed by less invasive methods. Pleural biopsy; closed pleural biopsy, biopsy under CT or thoracoscopic biopsy. Under CT, pleural biopsy provides reliable results when the pleural thickening is over $1 \mathrm{~cm}[8,9]$.

\section{Video assisted thoracoscopic surgery (VATS) - Thoracotomy (Open pleural biopsy)}

Pleural biopsy with VATS provides both inspecting pleural surfaces, performing biopsy from the suspicious regions of the pleura and draining the effusion at the same time [5]. It can be done under intubated general anesthesia; also, can be done under non-intubated general anesthesia or paravertebral block/ thoracal epidural anesthesia.

Open pleural biopsy with thoracotomy is a useful choice in cases where pleural leaves are over-thickened and pleural space is absent due to cohesions between pleural leaves as shown (Figure $3 A$ and $B)$. 


\section{References}

1 Rusch VW (2002) Pleural effusion: benign and malignant. In: Thoracic Surgery, $2^{\text {nd }}$ edn. Churchill Livingstone, New York, pp: 1157-1170

2 Shields TW (2007) Anatomy of the pleura. In: General thoracic surgery, $7^{\text {th }}$ Edn. Lippincott Williams \& Wilkins, Philadelphia, USA, pp: 729-735.

3 Yataco JC, Dweik RA (2005) Pleural effusions: Evaluation and management. Cleve Clin J Med 72: 854-872.

4 Light RW (2001) Pleural Diseases. $4^{\text {th }}$ Edn. Lippincott Williams \& Wilkins, Phialdelphia, USA.
5 Light RW (2002) Diagnostic approach in a patient with pleural effusion. Eur Respir Mon 22: 131-145.

6 Winterbauer RH (1998) Nonmalignant pleural effusions. In: Fishman AP (Edn). Fishman's pulmonary diseases and disorders. New York: McGraw-Hill, pp: 1411-1427.

7 Zimmerman LH (1997) Pleural effusions. In: Goldstein RH, O'Connell JJ, Karlinsky JB (Eds). A practical approach to pulmonary medicine. Philadelphia: Lippincott-Raven, pp: 195-205.

8 Light RW (2002) Pleural effusion. N Eng J Med 346: 1971-1977.

9 Light RW (1997) Diagnostic principles in pleural disease. Eur Respir J 10: 476-481. 